\title{
Rice Production Prospects in Eritrea
}

\author{
Ramesh Prasad Tripathi*, Woldeselassie Ogbazghi, Semere Amlesom \\ Department of Land Resources and Environment, Hamelmalo Agricultural College, Keren, Eritrea \\ Email: *rp.tripathi52@gmail.com,wogbazghi@gmail.com,semereamlesom@gmail.com
}

Received 17 June 2015; accepted 8 December 2015; published 11 December 2015

Copyright (C) 2015 by authors and Scientific Research Publishing Inc.

This work is licensed under the Creative Commons Attribution International License (CC BY).

http://creativecommons.org/licenses/by/4.0/

c) (†) Open Access

\begin{abstract}
Rice is not cultivated in Eritrea because of its high water requirements and arid to semiarid conditions. However, most agricultural watersheds in Eritrea are associated with $>\mathbf{8 0} \%$ non-agricultural lands, which produce significant runoff that can be diverted for use by rice crop. Experiments were conducted at Hamelmalo Agricultural College, Eritrea, using four NERICA rice varieties viz. N1, N4, N10 and N11 under rainfed (Io) and limited supplementary irrigations (I) in 3 replications. Results showed that plants were taller under limited irrigations than rainfed. Among the 4 varieties, N11 was most affected by water stress in which plant height was $0.72 \mathrm{~m}$ under rainfed and $0.89 \mathrm{~m}$ under limited irrigations. Effective tillers were highest (6) in N11 under limited irrigations and lowest (2) in $\mathrm{N10}$ under rainfed. Panicles were shorter $(0.20 \mathrm{~m})$ in $\mathrm{N10}$ and longer $(0.23-0.24$ $\mathrm{m}$ ) in N1 and N11. Irrigations delayed maturity by 6 - 15 days. Water use by N11 was higher both under limited irrigations $(987 \mathrm{~mm})$ and rainfed $(477 \mathrm{~mm})$ and lower by $\mathrm{N10}$ under rainfed $(457$ $\mathrm{mm}$ ). Root growth in all the varieties was better under irrigations (I) than rainfed (Io). Roots were limited to $0.7 \mathrm{~m}$ depth under rainfed (Io) but grew down to $0.8 \mathrm{~m}$ in N1, N4 and N11 under limited irrigations (I). Roots in N10 were limited to $0.5 \mathrm{~m}$ depth under Io and $0.7 \mathrm{~m}$ under $\mathrm{I}$. More than $63 \%$ roots in $\mathrm{N10}$ were in $0-0.1 \mathrm{~m}$ layer under rainfed as against less than $55 \%$ under limited irrigations. In lower layers, roots under Io were more in $\mathrm{N} 4$ than others, which is a beneficial trait for better performance under semiarid environments. Roots in N11 were better and uniformly distributed in lower layers under irrigated conditions. Rooting patterns and grain yields showed that N11 was most responsive to irrigations but susceptible to water stress and N4 was best under rainfed followed by N10. N4 was next to $\mathrm{N11}$ under irrigated conditions.
\end{abstract}

\section{Keywords}

Irrigated and Rainfed Rice, NERICA Rice, Eritrea, Root Growth, Water Use, Yield

\section{Introduction}

Rice is staple food in Eritrea. However, it is not cultivated in the country because of its high water requirements, *Corresponding author. 
semiarid to arid conditions and highly permeable soils in the areas where temperatures favor its growth. Rice likes soil water regime from field capacity to shallow submergence in which relatively high percolation loss is inevitable in coarse textured soils [1] [2]. However, irrigations at 6 - 8 days interval can also assure good crop under proper choice of variety and management conditions [1] [3]-[5].

Despite growing demand of rice as food in Eritrea, no systematic efforts were made to popularize its cultivation in the country. Some experiments were conducted by National Agricultural Research Institute (NARI), Halhale using NERICA (New rice for Africa) varieties but results were discouraging [6]. NERICA is a cross of African rice (Oryza glaberrima), perhaps the Nigerian origin [7], and Asian rice (Oryza sativa), which can be grown under limited irrigation conditions [8]-[10]. Average water requirements of NERICA were about $800 \mathrm{~mm}$ for 115 days crop yielding $2-4 \mathrm{t} \cdot \mathrm{ha}^{-1}$ [10] [11]. Encouraged by these results experiments were conducted at Hamelmalo Agricultural College, which provided ground for further research under runoff farming conditions by diverting part of the runoff generated on conventional agricultural watersheds into rice fields at downstream end of the watershed. Normally such fields in all agricultural watersheds in potential rice areas in Eritrea receive recurrent floods rendering them unsuitable for crop production during rainy season. Because of largely hilly terrains, Eritrea has limited potential lands (17.2\% of the total) that can be used for agriculture [12]. In view of the possible availability of additional water, efforts were made to study the prospects of rice cultivation at Hamelmalo.

\section{Experimental Details}

Experiments were conducted to evaluate performance of 4 NERICA rice varieties during rainy season of 2012 in a conservation bench terrace at foot of the sloppy land in a model watershed at Hamelmalo Agricultural College. Air temperatures during the crop season ranged from $35^{\circ} \mathrm{C}$ (maximum) to $16^{\circ} \mathrm{C}$ (minimum) and the rainfall was $346 \mathrm{~mm}$. The experiment was laid out in split plot design with varieties viz. N1, N4, N10 and N11 in main plots and 2 irrigation levels viz. rainfed (Io) and limited supplementary irrigations (I) in subplots in 3 replications. The net plot was $3 \mathrm{~m} \times 3 \mathrm{~m}$ with $1.5 \mathrm{~m}$ passage between the plots and replications. Bunds of height $0.3 \mathrm{~m}$ were made around each plot to prevent runoff. Entire experimental area was surrounded by a trench to avoid run-on. Seedlings were raised in nursery about 21 days before transplanting in the puddled plots. Nursery raising reduced crop duration with low water demand compared to that in the field and assured plant density by transplanting.

\subsection{Field Preparation and Transplanting}

Puddling was done to ease transplanting and reduce percolation rate. Fertilizers applied were urea and DAP at the rate of $120 \mathrm{~kg} \mathrm{~N}$ and $60 \mathrm{~kg} \mathrm{P} \mathrm{ha}^{-1}$. Entire DAP was applied as basal dose during last puddling operation and the remaining $\mathrm{N}$ was applied through urea in two equal splits at 20 days interval from transplanting. Single seedling from 21-day old nursery was transplanted in puddled plots in the first week of July at $0.2 \mathrm{~m}$ interval between rows and $0.15 \mathrm{~m}$ within row. About $80 \mathrm{~mm}$ irrigation was applied for puddling that maintained 30 - 50 $\mathrm{mm}$ submergence during transplanting. Shallow submergence of $10-20 \mathrm{~mm}$ was maintained in all the plots by irrigation during rainless periods for about 10 days for initial establishment. Weeding was done 3 times at an interval of 15 - 20 days from transplanting. Measurements were made of water use, plant growth and yield.

\subsection{Water Use, Growth and Yield}

Since seepage and percolation (PC, $\mathrm{mm}$ ) are inseparable parts of water requirement of rice, evapotranspiration (ET, mm) and PC losses from transplanting to harvesting were considered as total water use (TWU, mm), determined as

$$
\mathrm{TWU}=\mathrm{ET}+\mathrm{PC}=\mathrm{IR}+\mathrm{RF}_{\mathrm{e}}+\mathrm{DP}+\mathrm{WT}-\mathrm{RO}
$$

where IR is irrigation during the growing season $(\mathrm{mm}), \mathrm{RF}_{\mathrm{e}}$ is effective rainfall from transplanting to harvesting $(\mathrm{mm})$, DP is soil moisture depletion, which is change in soil moisture in the root zone from transplanting to harvesting $\left(\mathrm{mmm}^{-1}\right)$, WT is water table contribution $(\mathrm{mm})$, which was zero because water table was below $5 \mathrm{~m}$ depth and RO is total runoff $(\mathrm{mm})$. There was no runoff as the plots were well bunded and rainfall never exceeded the amount causing overflow during the growing season. Rice roots were observed down to $0.8 \mathrm{~m}$ and, therefore, soil moisture depletion was considered from I.0 m profile. In general, $50 \mathrm{~mm}$ irrigation was given in 
irrigated plots whenever rainless days exceeded beyond a week at any stage of the rice crop.

Effective tillers and plant height were measured at full grain development stage. Ear with grain bearing tillers were counted in three hills in each plot and were reported as effective tillers per plant. Plant height was measured from base of the plant. Root length density (RLD) and \% root distribution were determined at harvesting by line intersection method [13]. Core samples were drawn from each treatment in $0.10 \mathrm{~m}$ depth increments down to $1 \mathrm{~m}$ by placing $0.1 \mathrm{~m}$ diameter root core sampler over the harvested hill. The samples were washed and number of roots with vertical and horizontal grid lines of $10 \mathrm{~mm}$ were counted by spreading on a dish with a film of water to calculate RLD $\left(\mathrm{cm}^{\circ} \mathrm{cm}^{-3}\right)$ and \% root distribution as

$$
\mathrm{RLD}=\frac{R}{V}
$$

where $R$ is root length, $\mathrm{cm}$, expressed as

$$
R=\frac{11}{14} N \text { Grid units }
$$

where $N$ is number of intersections and $V$ is soil core volume, $\mathrm{cm}^{3}$. Percent root distribution was calculated as

$$
\% \text { Root distribution }=\frac{\text { RLD in ith layer }}{\text { Total RLD }}
$$

Grain and straw yields were determined by harvesting central $2 \mathrm{~m} \times 2 \mathrm{~m}$ plot. The harvested biomass was dried in the field for 3 days and weighed before threshing manually. Weight of grain was reported at $14 \%$ seed moisture and expressed in $\mathrm{kg} \cdot \mathrm{ha}^{-1}$. Total above ground biomass minus grain yield was the straw yield.

\section{Experimental Results}

\subsection{Plant Growth}

Irrigations were generally not needed until September 10 (end of rainy season) and, therefore, treatment differences between irrigated (I) and rainfed (Io) treatments during this period were negligible (Figure 1). However, by maturity plants were taller under irrigation than rainfed (Table 1). Effect of water stress was greatest on N11 in which plant height ranged from $0.72 \mathrm{~m}$ under rainfed to $0.89 \mathrm{~m}$ under irrigations. In all other varieties differences in plant height were $0.03-0.06 \mathrm{~m}$. Effective tillers were more under irrigated than rainfed. Tillers were highest (6) in N11 under limited irrigations and lowest (2) in N10 under rainfed. Panicles were shorter in N10 $(0.20 \mathrm{~m})$ and longer in N1 and N11 $(0.24 \mathrm{~m})$. Duration of N11 was highest (125 days after transplanting) under irrigated conditions and that of N10 was lowest (105 days from transplanting) under rainfed. Irrigations delayed maturity by 5 - 15 days from rainfed. The maximum difference was in N11. Water use was maximum by N11 both under irrigated $(987 \mathrm{~mm})$ and rainfed $(477 \mathrm{~mm})$ conditions and minimum by N10 under rainfed $(457 \mathrm{~mm})$. Water used in puddling $(80 \mathrm{~mm})$ ensured soil moisture saturation and thus seedling establishment.

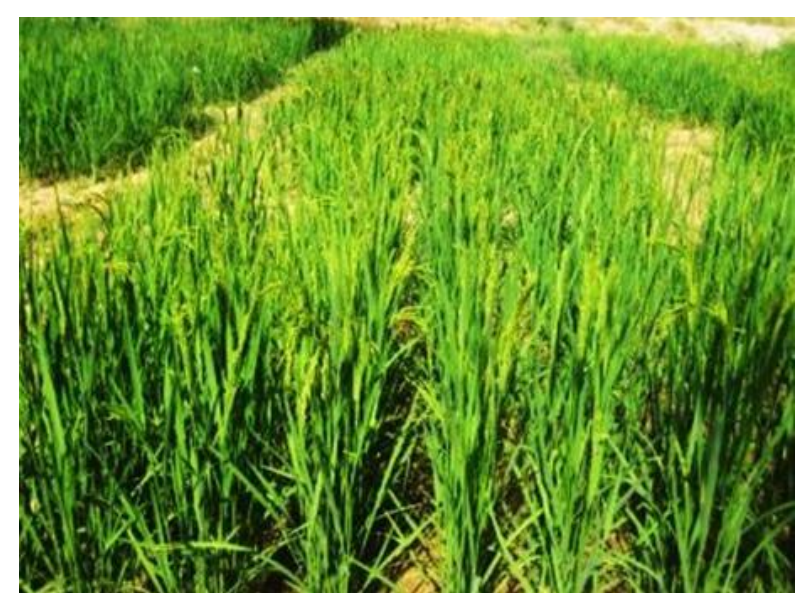

Figure 1. Rice crop at panicle initiation stage. 


\subsection{Rooting Pattern}

In general root growth was better under irrigated conditions than rainfed (Figure 2). Roots under rainfed (Io) were limited to $0.5 \mathrm{~m}$ depth in N10, $0.7 \mathrm{~m}$ in N1 and N11 but grew down to $0.8 \mathrm{~m}$ in N4.Under limited irrigations, roots in N1, N4 and N11 grew down to $0.8 \mathrm{~m}$ but were limited to $0.7 \mathrm{~m}$ depth in N10. About $63.5 \%$ of the roots of N10 under rainfed and 54.8\% under limited irrigations were concentrated in 0 - $0.1 \mathrm{~m}$ layer. In all other varieties roots in $0.1 \mathrm{~m}$ layer were between $20 \%-33 \%$. Although N10 lacks deeper roots, it may perform well under rainfed if rainfall is more uniform. Among N1, N4 and N11, maximum concentration of roots in $0-0.2 \mathrm{~m}$ layer was in N4 followed by in N11. Roots in N4were more than other varieties in lower layers, which is a beneficial trait for drought resistance [3] [10]. In N11, root growth was better and more uniform in lower layers under irrigated conditions. Although more study is needed on N11 to differentiate from others yet it shows better response under limited irrigations.

\subsection{Grain Yield}

Grain yields were significantly affected by varieties as well as irrigations (Table 2). Mean yields due to varieties
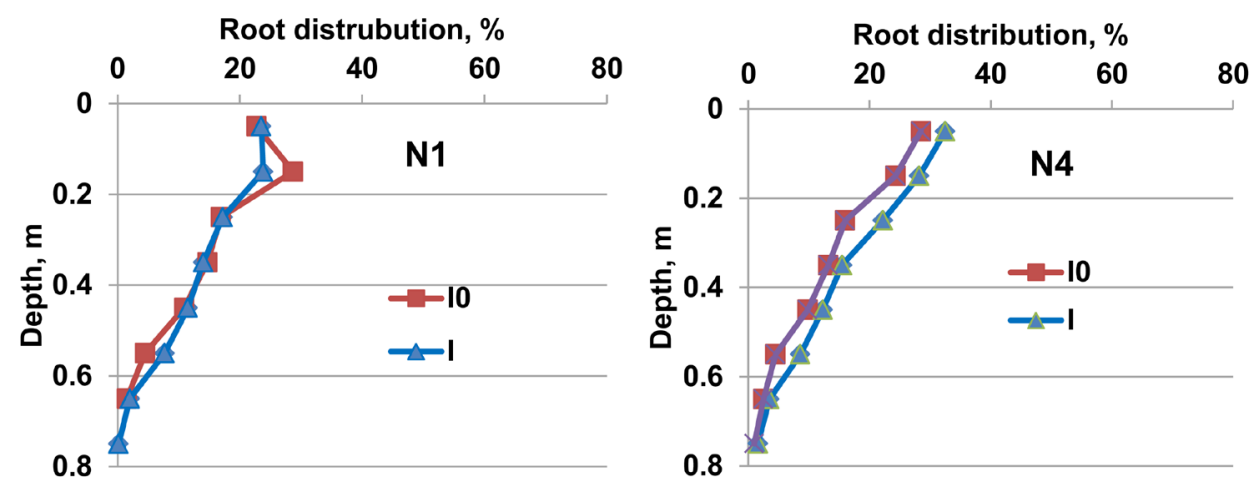

Root distribution, \%
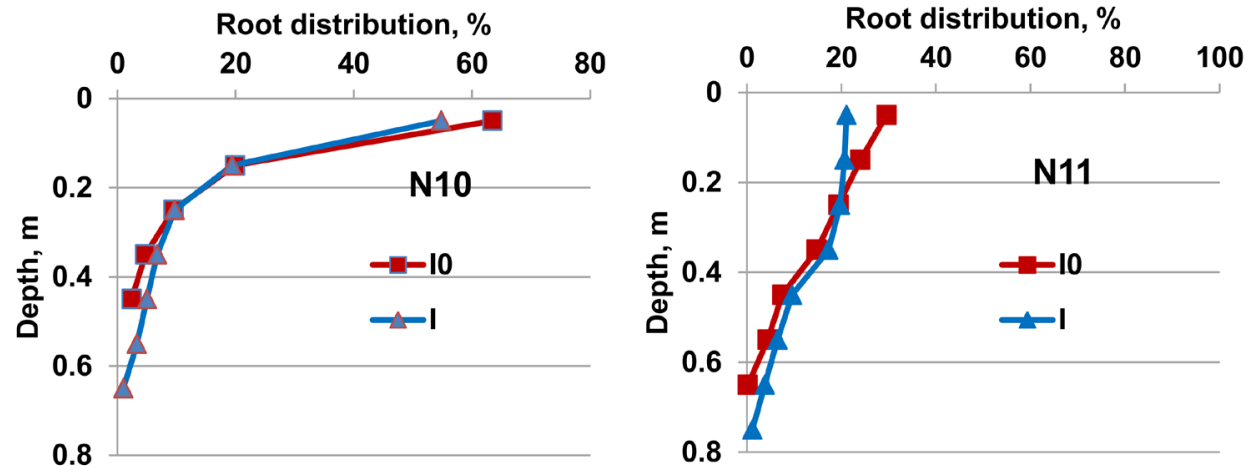

Figure 2. Rooting pattern of four NERICA rice varieties.

Table 1. Plant growth pattern under rainfed and irrigation conditions.

\begin{tabular}{|c|c|c|c|c|c|c|c|c|c|}
\hline \multirow[t]{2}{*}{ Variety } & \multicolumn{2}{|c|}{ Plant height, m } & \multicolumn{2}{|c|}{$\begin{array}{l}\text { Effective tillers } \\
\text { per plant }\end{array}$} & \multirow{2}{*}{$\begin{array}{l}\text { Panicle } \\
\text { length, } m\end{array}$} & \multicolumn{2}{|c|}{ Days to maturity } & \multicolumn{2}{|c|}{ Water use, mm } \\
\hline & Io & I & Io & I & & Io & I & Io & I \\
\hline N1 & 0.87 & 0.90 & 4 & 5 & 0.24 & 115 & 120 & 471 & 980 \\
\hline N4 & 0.85 & 0.90 & 4 & 5 & 0.23 & 115 & 121 & 459 & 977 \\
\hline N10 & 0.77 & 0.83 & 2 & 5 & 0.20 & 105 & 115 & 457 & 939 \\
\hline N11 & 0.72 & 0.89 & 3 & 6 & 0.24 & 110 & 125 & 477 & 987 \\
\hline
\end{tabular}

Io = Rainfed; I = Irrigated. 
Table 2. Grain yield of four rice varieties under irrigated and rainfed conditions.

\begin{tabular}{cccc}
\hline \multirow{2}{*}{ Variety } & & Grain Yield, $\mathrm{kg}^{\circ} \mathrm{ha}^{-1}$ & Mean \\
\cline { 2 - 3 } & Rainfed, Io & Irrigated, I & 2602 \\
N1 & 1990 & 3215 & 3350 \\
N4 & 2500 & 4200 & 2697 \\
N10 & 1945 & 3450 & 3033 \\
N11 & 1151 & 4915 & $\mathrm{~V} \times \mathrm{I}$ \\
Mean & 1827 & 4064 & 1032 \\
Factors & Varieties, V & Irrigation, I & 516 \\
LSD at 5\% & 318 & & \\
\hline
\end{tabular}

were at par in N4 and N11 but significantly greater than in N1 and N10 in which they were at par. Mean yields due to irrigations were more than 2.2 times that under rainfed. Interaction effects showed that N11 was most responsive to irrigations followed by N4 in which yields were at par. Grain yields showed that N4 was best under rainfed followed by N10 and N1, in which yields were at par. N11 was susceptible to soil water deficit below field capacity. N4 was resistant to water stress and stood second best under irrigated conditions.

\section{Conclusions}

1) Rice can be grown in Eritrea by diverting runoff generated in agricultural watersheds into rice fields at downstream end of the watershed.

2) NERICA varieties, such as N4, can withstand water stress and N11 can respond to irrigations as Asian varieties.

3) Shorter duration NERICA varieties maturing in about $100 \pm 5$ days under limited irrigation conditions will have better prospects in Eritrea.

\section{Acknowledgements}

Authors are grateful to the Centre for Development and Environment, Institute of Geography, University of Berne, Switzerland for providing financial support through Eastern and Southern Africa Partnership Programme to carry out this research. Authors are also grateful to Mr. Tseneo Tsrusaki, Japanese International Cooperation Agency, Asmara, Eritrea for supplying seed of the four NERICA varieties.

\section{References}

[1] Tripathi, R.P., Kushwaha, H.S. and Mishra, R.K. (1986) Irrigation Requirement of Rice under Shallow Water Table Conditions. Agricultural Water Management, 12, 27-36. http://dx.doi.org/10.1016/0378-3774(86)90011-9

[2] Bajpai, R.K. and Tripathi, R.P. (2000) Evaluation of Non-Puddling under Shallow Water Tables and Alternative Tillage Methods on Soil and Crop Parameters in a Rice-Wheat System in Uttar Pradesh. Soil \& Tillage Research, 55, 99106. http://dx.doi.org/10.1016/S0167-1987(00)00111-2

[3] Tripathi, R.P. and Singh, R. (1988) Remote Sensing of Drought Resistance in Rice. Proceedings of National Symposium on Remote Sensing in Rural Development, HAU, Hisar, 17-22.

[4] Mohyuddin, J. and Tarique, M. (2010) Evaluation of Irrigation Application Methods for Rice Production. Sarhad Journal of Agriculture, 26, 577-582.

[5] Ashouri, M. (2012) The Effect of Water Saving Irrigation and Nitrogen Fertilizer on Rice Production in Paddy Fields of Iran. International Journal of Bioscience, Biochemistry and Bioinformatics, 2, 56-59. http://dx.doi.org/10.7763/IJBBB.2012.V2.70

[6] National Agricultural Research Institute (NARI) Eritrea (2001-2003) Reports on Introduction of Conservation Agriculture in Eritrea, and Conservation Agriculture in Eritrea.

[7] Wopereis, M.C.S., Defoer, T., Idinoba, P., Diack, S. and Dugué, M.J. (2009) Participatory Learning and Action Research (PLAR) for Integrated Rice Management (IRM) in Inland Valleys of Sub-Saharan Africa: Technical Manual. WARDA Training Series. Africa Rice Center, Cotonou, 128 pp. 
[8] Bunyatta, D.K. (2012) Guideline for Growing New Rice for Africa (NERICA): An Upland Rice Variety as an Alternative Food Security Crop in Semiarid Lands of Kenya. Ministry of Agriculture, PDA'S Office Nairo Province, Nairobi.

[9] Adiam, B.Z., Hadish, H. and Issak, T. (2013) Water Requirement, Growth and Yield of Four Rice Varieties at Hamelmalo Agricultural College. Senior Research Paper, Department of Land Resources and Environment, Hamelmalo Agricultural College, Eritrea.

[10] Jahan, M.S., Mohd, N., Bin, N.M.K. and Yuso, M.K. (2013) Effects of Water Stress on Rice Production: Bioavailability of Potassium in Soil. Journal of Stress Physiology \& Biochemistry, 9, 97-107.

[11] West Africa Rice Development Association (WARDA) (2006) Perspective Rice Development in Sub-Saharan. Africa Journal of the Science of Food and Agriculture, 86, 675-677. http://dx.doi.org/10.1002/jsfa.2415

[12] Ministry of Agriculture (MOA) (2005) Area and Production by Zoba from 1992-2005.

[13] Tennant, D. (1975) A Test of Modified Line Intersect Method of Estimating Root Length. Journal of Ecology, 63, 9951001. http://dx.doi.org/10.2307/2258617 